\title{
Polychaetes associated to a Cymodocea nodosa meadow in the Canary Islands: assemblage structure, temporal variability and vertical distribution compared to other Mediterranean seagrass meadows
}

\author{
Mari Carmen Brito ${ }^{1}$, Daniel Martin² \& Jorge Núñez ${ }^{1}$ \\ ${ }^{1}$ Laboratorio de Bentos, Departamento de Biología Animal, Facultad de Biología, Universidad de La Laguna, 38206 \\ La Laguna, Tenerife, Canary Islands, Spain \\ ${ }^{2}$ Centre d'Estudis Avançats de Blanes (CSIC), Carrer d'accès a la Cala Sant Francesc 14, 17300 Blanes, Girona, \\ Catalunya, Spain. Fax: 34 972337806. E-mail: dani@ceab.csic.es
}

\begin{abstract}
The structure, diversity and temporal distribution of the infaunal polychaetes associated to Cymodocea nodosa meadows were studied in Tenerife (Canary Islands). The samples were collected monthly throughout a year, to depths between 13-16 m. The sediment was extracted by means of PVC cores, in which four layers were separated (i.e., 0-5 cm, 5-10 cm, 10-20 cm and 20-30 cm). 1,167 polychaete specimens, belonging to 69 taxa were collected, representing one of the most dominant groups in the benthic assemblage throughout all the year. The most common families were Syllidae, Paraonidae and Spionidae, both in terms of abundance and species richness. The dominant species were Streptosyllis bidentata, Aricidea assimilis and Exogone parahomoseta mediterranea, resulting also the only constant species throughout the year. The highest values of species richness, diversity, equitability and abundance of polychaetes occurred in September. The multifactorial analysis of abundances (i.e. cluster analysis and non-metric multi-dimensional scaling) indicated a temporal segregation of samples from July, August and September (i.e. the warmest months) with respect to those of the rest of the year, due to structural differences in the assemblage. Polychaete species have been found up to $30 \mathrm{~cm}$ depth in the sediment. Nevertheless, most of them (89\%) occurred in the first $5 \mathrm{~cm}$ of the sediment, with an increase of specimens in deeper layers in February (i.e., due to punctual episodes of higher hydrodynamics). To compare the vertical distribution of polychaetes, additional core samples were collected in two seagrass meadows (i.e., C. nodosa and Ruppia cirrhosa) at the Ebro's Delta (NW Mediterranenan), in which five layers were separated (i.e. 0-5 cm, 5-10 cm, 10-15 cm, 15-20 cm, 20-25 cm). The results obtained in the $R$. cirrhosa meadow ( $98 \%$ of the polychaetes within the first $5 \mathrm{~cm}$ ) agrees with those in the Canarian $C$. nodosa meadow, while the polychaetes reached up to $15 \mathrm{~cm}$ deep in a $C$. nodosa meadow (i.e., $\approx 39 \%$ between $0-5 \mathrm{~cm}, \approx 41 \%$ between $5-10 \mathrm{~cm}, \approx 20 \%$ between $10-15 \mathrm{~cm}$ ). Our results supported that the structural characteristics of the assemblages appeared to be more strongly controlled by the combined characteristics of the sediment (i.e. lack of oxygen, granulometry and degree of compaction) than by the seagrass species building the meadow.
\end{abstract}




\section{Introduction}

The most dominant and widely distributed seagrass in the Canary Islands is Cymodocea nodosa (Ucria) Ascherson. The species grows in sandy sublittoral bottoms, forming dense meadows (Alfonso-Carrillo and Gil-Rodríguez 1980; Reyes 1993), which can be monospecific or constitute mixed populations with the green algae Caulerpa prolifera (Försskal) Lamouroux and $C$. racemosa (Försskal) Agardh, that replaces it in deeper bottoms and, sometimes, in sites affected by human activities. $C$. nodosa occurs both in protected and semi-exposed areas of the southeastern and southwestern coasts of almost all the islands, from intertidal pools in sheltered sites to 35-40 $\mathrm{m}$ in depth. C. nodosa is considered as a pioneer species in the colonization of soft substrata, being able to form meadows in absence of other accompanying species (Molinier and Picard 1952). The studies on $C$. nodosa from Canary Islands show that its biological cycle is very similar to that observed in the Mediterranean. However, the formation of the fruit is earlier and the density of flowers and the number of fruits by $\mathrm{m}^{2}$ is higher in the Canary Islands (Reyes 1993).

The polychaete populations have been considered excellent descriptors of the faunal communities associated to seagrassess, due to the great diversification of species and life habits (Hutchings 1982; Somaschini et al. 1994) including small-sized species, as C. nodosa (Lanera and Gambi 1993; Gambi et al. 1998). In the Canary Islands, there are several studies dealing with the taxonomy of polychaetes harboured in C. nodosa meadows (Brito et al. 2000a, 2000b, 2001; Brito and Núñez 2002). Nevertheless, little is known on the ecology and structure of the associated assemblages. In other geographic areas, numerous studies have been carried out on this topic, mainly on the polychaetes associated to Posidonia oceanica (L.) Delile, (Colognola et al. 1984; Alós 1988; Somaschini et al. 1994; Gambi et al. 1995). All them agree in pinpointing high diversity and species richness of these ecosystems (Young and Young 1977; Kikuchi 1980; Howard et al. 1989). Among the studies on small-sized seagrass beds (like C. nodosa or Ruppia cirrhosa), those made in the Mediterranean are of special relevance to be compared with the present study (True-Schlenz 1965; Giangrande and Gambi 1986; Palacín et al. 1991; Lanera and Gambi 1993; Martin et al. 1993; Gambi et al. 1995, 1998; Martin et al. 2000).

The analysis of the benthos is very important to facilitate future monitoring studies in $C$. nodosa meadows, since benthic organisms are among the first responding to the stress caused by 
organic enrichment (Bilyard 1987). The variability of the distribution patterns of these organisms is an excellent tool allowing to determine the vulnerability to disturbance (Rizzo and Amaral 2000). Thus, the present study focused on the polychaete taxocoenosis, which play the most relevant contribution in the structure of the assemblage harboured by C. nodosa. Its temporal variability and vertical distribution in the sediment in a fixed station in Tenerife (Canary Islands) were analyzed. Moreover, it has been possible to compare the vertical distribution of the Canarian assemblages with some additional data obtained form the bay of Els Alfacs (Ebro's Delta, NW Mediterranean) for the infauna associated to C. nodosa and Ruppia cirrhosa Petagna (Grande). The results are also compared with those obtained by other authors for $C$. nodosa and Zostera noltii Mediterranean meadows.

\section{Materials and Methods}

Study sites

The present study was mainly carried out in the Ensenada de los Abades, SE of Tenerife (Canary Islands) (Fig. 1a). The northern cove limits are defined by the volcano Punta de los Abades, which is partially destroyed by the marine abrasion, while several abrupt cliffs form the southern limits. The beach, located between two points (Los Abades and Los Jureles), is mainly formed by boulders and Holocene sand.

The water temperature during the study period ranged between $18.5^{\circ} \mathrm{C}$ in winter and $22.5^{\circ} \mathrm{C}$ in summer. This southeastern coastal region of Tenerife is protected leeward from the influence of the Canarian Current and the NE trade winds. These zones of the island allow the development of extensive $C$. nodosa meadows. Populations of Lobophora variegata, Cystoseira abies-marina, C. humilis, Sargassum vulgare and Asparagopsis armata form the shallow-water infralittoral photophylic algae of the beach, while more sciaphylic zones are inhabited by Codium intertextum. Down to $3 \mathrm{~m}$ deep, the bottoms are occupied by the community of "blanquizal", characterized by the presence of bare rocky surface without seaweeds due to the intense grazing of the sea urchin Diadema antillarum. Sandy bottoms start at $12 \mathrm{~m}$ deep with an assemblage characterized by the presence of the gardener-eel, Heteroconger longissimus, and the $C$. nodosa meadow starts at $13 \mathrm{~m}$ deep. Although some $C$. nodosa meadows may have a dense interlace of rhizomes and roots, the "turf" (Buia et al. 1985; Terlizzi and Russo 1998), the meadows in Ensenada de los Abades are very sparse due to the strong currents characterising the hydrodynamics of the zone.

Additional samples to analyze the vertical distribution were obtained in the Bay of Els Alfacs, a semi-enclosed shallow water area located in the Ebro's Delta, Catalan coasts of the NW Mediterranean (Fig. 1b). Els Alfacs is the southern Bay of the Delta. It has an area of about $50 \mathrm{Km}^{2}$, a mouth of $3 \mathrm{Km}$ connecting to the sea and an average depth of $4 \mathrm{~m}(\max .=6 \mathrm{~m})$. The Bay has a central deeper area and a littoral shelf between 0 and $2 \mathrm{~m}$ deep. The Bay is 
mainly characterized by a marine hydrographical regime, but is also influenced by fresh-water inputs occurring during spring and summer (Palacín et al. 1991). In absence of strong winds, there is still an exchange between the Bay and the open sea either following a periodicity of ca 10 days or through a typical estuarine circulation (Camp et al. 1991). As a result, the organic inputs coming from fresh waters (i.e. about $62 \mathrm{mg} \mathrm{C} \mathrm{m}^{-2}$ day $^{-1}$ ) mainly affected the northern sections of the littoral shelf, where the Ruppia meadows were located, but they scarcely reached southern sections of the shelf, where the Cymodocea meadows occurred, prior to flow out of the Bay towards the open sea (Palacín et al. 1991; Martin et al. 1993, 2000).

Field sampling and sediment analyses

In the Ensenada de los Abades, the samples were collected from 13 to $16 \mathrm{~m}$ depth from January to December 1994 by direct sampling. We used PVC corers of $4.5 \mathrm{~cm}$ inner diameter, which were pushed in the substrate to $30 \mathrm{~cm}$ in depth to provide sediment volumes of $450 \mathrm{~cm}^{3}$ per corer. The habitual depth in studies dealing with vertical distribution of infauna based on manual sampling oscillates between $6 \mathrm{~cm}$ for a muddy beach (Cruz and Vargas 1987) and $40 \mathrm{~cm}$ for the infauna of other environments (Bloom et al. 1972). However, this last depth seems to be excessive and the most used the one is of $20 \mathrm{~cm}$ (Whitlatch 1977). Therefore, to prevent possible losses of information, we have used $30 \mathrm{~cm}$ depth corers because the high hydrodynamics linked to the island environment favours increased oxygenation of the sediment, this resulting in a deeper anoxic layer and potentially increased depth penetration of the infauna. A similar reason was the basis for collecting samples only up to $25 \mathrm{~cm}$ into the sediment for the Bay of Els Alfacs.

In the Ensenada de los Abades, five core replicates were obtained monthly. One of them was used to determine the granulometry and the structural and chemical variables of the sediment. All 48 samples dedicated to the faunal study, were subdivided in four layers (i.e. 0-5 cm, 5-10 cm, 10-20 cm, 20-30 cm) to analyze the vertical distribution of polychaetes. The samples were fixed with a $4 \%$ formaldehyde/seawater mixture prior to sieving though a $100 \mu \mathrm{m}$ pore size mesh. The polychaetes were separated from the rest of the fauna, including all larval, juvenile and adult stages, then preserved in $70 \%$ ethanol. In the Bay of Els Alfacs, four replicates were obtained from each seagrass meadow in early summer. All them were subdivided into five layers (i.e. 0-5 cm, 5-10 cm, 10-15 cm, 15-20 cm, 20$25 \mathrm{~cm}$ ) prior to be fixed with a $4 \%$ formaldehyde/seawater. All infaunal organisms were sorted and preserved in $70 \%$ ethanol.

In the Ensenada de los Abades, the granulometry of the sediment was obtained from subsamples of 100 gr. The sediment was first dried at ambient temperature and then sieved through to graded series of sieves following the Wentworth procedure (Buchanan and Kain 1971; Buchanan 1984). The percentage of organic matter was estimated according to the Walkley (1947) method (adapted and modified by Jackson, 1960). The carbonate content was estimated according to the Allison and Moodie (1965) method, and the analysis of nitrogen followed the Kjeldahl method (Marr et al. 1990).

The analytical methods employed to define the sediment variables of the two stations in the Bay of Els Alfacs are fully described in Palacín et al. (1991) and Martín et al. (1993, 2000). 
Statistical analyses

In the Ensenada de los Abades, the structure of the polychaete assemblage was analyzed by means of the PRIMER 5.2.2 (C PRIMER-2000) software (Clarke and Warwick 1994) using two multivariate methods, cluster analysis and non-metric multi-dimensional scaling (MDS). The cluster analysis was based on the Bray-Curtis similarity index (Bray and Curtis 1957) and used the group average group method. The similarity matrix was based on four-root transformed average abundances. No reductions in species number were applied. Sample segregation was perfectly explained by a two-dimension MDS ordination. The ANOSIM routine (Clarke 1993; Clarke and Warwick 1994) based on replicate abundances was used to analyze the temporal variability. The polychaete species responsible for the observed patterns were identified by means of the SIMPER routine (Clarke and Warwick 1994). The indices of species diversity ( $\mathrm{H}^{\prime}$, Shannon and Weaver 1949), evenness (J, Pielou 1969) and Simpson dominance were calculated. The Soyer's dominance and frequency indexes were calculated and the species were classified as Dominant $(\mathrm{D}$, dominance $\geq 1 \%$ ) or non-dominant (d, dominance $<1 \%)$, and as Constant $(\mathrm{C}$, frequency $\geq 50 \%$ ), Accessory (A, 25\% < frequency $<50 \%$ ) or Accidental (frequency $\leq 25 \%$ ) (Soyer 1970).

The temporal trends shown by the biological descriptors of the polychaete assemblages from the Ensenada de los Abades, and their differences when grouped according to the results of the multivariate analysis, were analyzed by means of parametrical one-way analysis of variance (ANOVA) and the differences in vertical distribution in the different meadows by two-way ANOVA. To compare the Canarian and Catalan meadows, sediment layers were grouped in three deep ranges (i.e. 0-5 cm, 5-10 cm and the remaining layers pooled all together). Post hoc multiple comparisons were carried out by means of the Tukey Honest Significance test (Tukey HSD) (Zar 1984). The data were either ranked (temporal trends and Groups) or square root transformed (vertical distribution) to meet the assumptions of normality and homoscedasticity required for parametrical analyses (Zar 1984).

\section{Results}

\section{Abiotic characteristics of sediments}

The granulometry of the sediment inside the $C$. nodosa meadows is characterized by the presence of fine sand in the first $20 \mathrm{~cm}$ and medium-sized sand from 20 to $30 \mathrm{~cm}$ deep. The most abundant grain size fractions are fine sands (42.4\%) and medium-sized sand (31.5\%). The very fine and fine fractions decrease with depth in the sediment, wile coarse fractions increase. The median range between $\mathrm{Q}_{50}=0.25-0.21$ (fine sand) between 0 to $20 \mathrm{~cm}$ and of $\mathrm{Q}_{50}=0.33-0.43$ (medium-sized sand) from 20 to $30 \mathrm{~cm}$. The sorting is moderate, $\mathrm{S}_{0}=1.77-1.58$, with a low pelitic content $(0.73 \%)$, as it corresponds to open zones with high hydrodynamics. 
The organic matter content is low, as it is common in oligotrophic oceanic waters, ranging between $0.54-0.16 \%$. The carbonate content is also quite low, with an average of $4.14 \%$, decreasing as going deep into the sediment. Nitrogen content is low too, ranging from $0.03 \%$ in the superficial layer to $0.02 \%$ in the deepest layer. These values are similar to those obtained in other areas of the Canary Islands, which are characterized by clean waters, with very little terrigenous runoff and far away from urban areas.

The sandy areas from the study site show differences with respect to the meadow sediments. The granulometry is characterized by coarse sand in the first $10 \mathrm{~cm}$ and medium-sized sand from 10 to $30 \mathrm{~cm}$ deep. The sorting is poor $\left(S_{0}=1.95\right)$. The organic matter reaches much lower average values $(0.03 \%)$, as well as the pelites $(0.29 \%)$, carbonates $(2.60 \%)$ and nitrogen $(0.02 \%)$. These results demonstrate that, by reducing flow, the $C$. nodosa meadows allow the settlement of fine particles of sediment and favour the increase of organic matter inside and along the neighbourhoods of the meadow.

The particular morphology and water circulation in the Bay of Els Alfacs generates two different environmental conditions at the two study areas. Consequently, the Ruppia meadows are characterized by sediments low Redox potential $(<-200 \mathrm{mE})$, high silt contents $(23-37 \%)$ and relatively high organic contents $(1.3-6.3 \%)$, while the Cymodocea meadows show sediments with high Redox potential $(-8.3-16.5 \mathrm{mE})$, low silt contents $(0.05-0.06 \%)$ and relatively low organic contents (0.6-0.7\%) (Palacín et al. 1991; Martin et al. 1993, 2000).

Systematics and faunistics

From a total of 3,985 specimens collected in the sediments associated to C. nodosa throughout the year, 21 higher taxa were identified: Amphipoda, Anthozoa, Copepoda, Cumacea, Decapoda, Gastropoda, Gastrotricha, Halacaridae, Isopoda, Kinorhyncha, Nematoda, Nemertina, Oligochaeta, Ophiuroidea, Ostracoda, Polychaeta, Pycnogonida, Rhizopoda, Sipuncula, Tanaidacea and Turbellaria. Among them, nematodes and polychaetes were dominant, including $34.8 \%$ and $29.9 \%$ of the abundance and $31.3 \%$ and $23.7 \%$ of the species richness, respectively.

A total of 1,167 polychaete specimens (including larval phases, juveniles and adults) belonging to 24 families have been collected. Of these, 69 taxa have been identified, 57 at species 
lever, 3 at genus and 9 forms of larval phases and juveniles. Syllidae and Paraonidae were the most abundant families throughout the year. Syllidae were also the richest family, followed by Spionidae, Paraonidae and Opheliidae. The assemblage showed a high diversity, with 16 dominant species. Among them, the most abundant were Streptosyllis bidentata, Aricidea assimilis, Exogone parahomoseta mediterranea and Cirrophorus perdidoensis (Table 1). Especially interesting is the high number of Streptosyllis spp. juveniles, which made this genus dominant in the assemblage. Their abundances clearly indicate a high reproductive potential of the species of this genus throughout the year. As for the frequency, three species were constant (A. assimilis, S. bidentata and E. parahomoseta mediterranea) and eight species were accessory (C. perdidoensis, Streptosyllis campoyi, Periquesta canariensis, Exogone breviantennata, Streptosyllis websteri, Capitomastus minimus, Streptosyllis templadoi and Exogone verugera).

\section{Multivariate analyses}

The structure of the polychaete assemblage throughout the year showed a very uniform pattern, with few differences between the groups of monthly samples (40\% of similarity). The Cluster analysis corresponding to the twelve months of the year (averaged means) produced a dendrogram with four clear groups (Fig. 2a), which were also revealed by the MDS (Fig. 2b). The samples clustered in Group I (58\% of similarity) corresponded to the colder months of the year, while those clustered in Group II (55\% similarity) corresponded to the three summer months. Group III corresponded to samples from a single month (June), while samples from February and May were included in Group IV, which cannot be considered as a strong cluster because of the linkage of the two months under a very low level of similarity (48\%).

The ANOSIM gave rise to a Global R of 0.221 (number of used permutations = 20,000; number of permutations equal or superior to the Global $\mathrm{R}=35$; significance level $=0.2 \%$ ). The population structure Group I significantly differed from Group II and did not differ significantly from Group IV (significance level of $17.4 \%$ and 12.2\%, respectively for February and May), while Group II differed significantly from Group IV (significance level of 0.3\%). In turn, Groups I and II differed significantly from Group III (significance level of 3.9\% and $0.7 \%$, respectively) 
and, although less robust due to the low sample number and used permutations (i.e. 35), significant differences also occurred between Groups III and IV.

In agreement with the rather uniform pattern shown by the structure of the polychaete assemblage throughout the year, a few significant differences were found between the groups identified in the multivariate analyses when analysing the main biological descriptors of the assemblage (Fig. 3). In fact, only the density and the evenness showed significant differences (F $=3.23, \mathrm{p}<0.03$ and $\mathrm{F}=4.52, \mathrm{p}<0.007$, respectively). The Tukey test indicated that Group III ( $\mathrm{p}$ $<0.04)$ and Group II $(\mathrm{p}<0.02)$ were the main responsible of the observed differences.

The species with greater similarity between all the samples studied were A. assimilis, $S$. bidentata, E. parahomoseta mediterranea, $C$. perdidoensis, $P$. canariensis and E. verugera. The greater dissimilarity between Groups I and II was caused by S. bidentata, C. perdidoensis, A. assimilis and E. verugera (more abundant in the former than in the latter group) and by $P$. canariensis and E. parahomoseta mediterranea (more abundant in the latter group) (Table 2). A. assimilis was the main responsible of the differences between Groups II and IV. S. bidentata was both the second contributor to the similarity throughout the year (except for Group II) and the major responsible of the dissimilarity between Group I and Groups II and IV. E. parahomoseta mediterranea was the major contributor to the dissimilarity between both Groups I and IV and Groups II and III. C. perdidoensis, $P$. canariensis and E. verugera caused a great dissimilarity between Group I, Group II and Group IV and the respectively remaining groups.

The samples from Group I showed an average similarity of $33.8 \%$ and were characterized by S. bidentata, A. assimilis, E. parahomoseta mediterranea, C. perdidoensis, C. minimus and E. breviantennata ( $81.6 \%$ of the similarity), with the first two being the most abundant and $P$. canariensis showong a remarkably low abundance (Table 2). Samples from Group II showed a $31.8 \%$ of average similarity and were characterized by E. parahomoseta mediterranea, $P$. canariensis, C. perdidoensis, S. campoyi, S. bidentata, A. assimilis and S. templadoi $190.7 \%$ of the similarity), the first two being the most abundant (Table 2). Among the characteristic species of Group IV, only three (i.e. A. assimilis, S. bidentata and E. verugera) coincided for the two sampling months. February and May were respectively characterized by C. minimus, S. websteri, Grubeosyllis clavata and by Microspio mecznikovianus, larvae of Opheliidae and Schroederella laubieri, while $P$. canariensis showed again a really low abundance in all samples (Table 2). The most characteristic species of Group III (June) were A. assimilis, S. bidentata, S. laubieri, 
Spiochaetopterus costarum, E. verugera, Armandia intermedia and S. templadoi, while the structure of their polychaete assemblages appeared as a transition between the colder (Groups I and IV) and warmer periods (Groups II).

The highest average dissimilarity occurred between Groups III and II (78.4\%), with the major responsible being E. parahomoseta mediterranea (less abundant in Group III and more abundant in Group II), P. canariensis and C. perdidoensis (present in Group II and absent in Group III), and S. laubieri (very abundant in Group III and scarce in Group II). The average dissimilarity between Groups I and III was also high (74.0\%), with the major contributors being S. laubieri (absent in Group I), C. perdidoensis (absent in Group III) and E. parahomoseta mediterranea and S. bidentata (highly abundant in Group I).

Univariate measurements of community structure

The temporal patterns of the main variables describing the structure of the polychaete assemblages tended both to be rather uniform all along the year and to have a high within replicates variability, this making difficult to asses the significance of the observed trends. In fact, only the abundance, the evenness and the dominance showed significant differences (Table 3).

The maximum polychaete densities ocurred in September, November and December (461.5, 451.8 and 438.8 ind. $\mathrm{m}^{-2}$, respectively), with secondary maxima in March and April (380.3 and 338.0 ind. $\mathrm{m}^{-2}$, respectively) and minimum values in May and June (139.8 and 175.5 ind. $\mathrm{m}^{-2}$, respectively) (Fig. 4a). The main responsible for the significant differences in the ANOVA (Table 3) were the high densities occurring in September (Tukey test, p < 0.05).

The number of species per sample showed an annual trend more uniform than that of the density (Fig. 4b), with a maximum in September (11.0 species) and minima in May and July (5.5 and 6.0 species, respectively). The global average of the number of species per month was 7.6. The Margalef species richness was also uniform throughout the year, the highest and minimum values being 2.99 and 1.59 in September and July, respectively (Fig. 4c).

The Shannon-Weaver diversity index was rather constant throughout the year, with the highest and lowest values being 2.11 (September) and 1.37 (December) and 1.42 (July) (Fig. 4d). 
Unusual low values of the Pielou's evenness index were observed in one sample during December, due to the high number of individuals of $C$. perdidoensis and E. parahomoseta mediterranea. Nevertheless, this index showed uniform values throughout the year, ranging between 0.79 (April and August) and 0.94 (May and June) (Fig. 4e), with the main responsible for the observed differences being the evenness low in August and high in May/June (Tukey test, $\mathrm{p}<0.02)$.

The values of the Simpson dominance index were very low (Fig. 5f), as it can be inferred from the high evenness registered throughout the year. The higher dominance occurred in May (0.34), with only 43 specimens and 11 species being collected. A secondary dominance maximum occurred in July (0.3), when only 67 specimens and 12 species were found. The lowest dominance index occurred in September and December (0.18), when the higher density, species richness and diversity values were observed. In that case, the main responsible for the observed differences were the lowest dominance in September and December (Tukey test, $\mathrm{p}<0.05$ ).

\section{Vertical distribution}

In the Ensenada de los Abades, most polychaete specimens inhabited the most superficial layer of sediment, between 0 and $5 \mathrm{~cm}$ of depth ( $89 \%$ of specimens), which represented about $30 \%$ of the total infauna found in this layer. A $9 \%$ occurred between $5-10 \mathrm{~cm}$ deep, a $1.3 \%$ between 10-20 $\mathrm{cm}$ deep and the remaining $0.7 \%$ between $20-30 \mathrm{~cm}$ deep, which represented from about 30 to a few less than $20 \%$ of the total infauna (Fig. 5). Not all polychaete species were able to inhabit the deeper layers of sediment. Several species of Paraonidae, Syllidae, Capitellidae and Questidae were the most frequent: A. assimilis, S. bidentata, P. canariensis, C. minimus, $C$. perdidoensis, $C$. armatus and E. breviantennata (between $5-10 \mathrm{~cm}$ deep); P. canariensis, A. assimilis, $S$. bidentata, E. verugera, S. campoyi, C. perdidoensis, C. armatus y C. minimus (between $10-20 \mathrm{~cm}$ deep), and Syllides japonicus, Grubeosyllis vieitezi y Polyophtalmus pictus (between $20-30 \mathrm{~cm}$ deep) (Table 4).

The maximum abundance in the deep layers of sediment $(20-30 \mathrm{~cm})$ occurred in February (33.3\%), with $7.4 \%$ of the total polychaetes. A secondary maximum occurred in August, with $17.7 \%$ of the specimens in the layer between $5-20 \mathrm{~cm}$ deep. Both maximum abundances in deep 
layers of sediment coincided with storms in the study zone. Thus, probably these particular environmental conditions (closely related to episodes of strong hydrodynamics) forced some species to migrate into the deeper layers of sediment. In contrast, no relevant differences were observed when analyzing the vertical distribution for the four groups obtained in the multivariate analyses, with the average percentage of density between $5-30 \mathrm{~cm}$ deep ranging between $10 \%$ and $12 \%$.

In the Bay of Els Alfacs, the most evident result when observing the vertical distribution of polychaetes (Table 5, Fig. 5) was the absence of organisms below $15 \mathrm{~cm}$ deep so that the two corresponding layers (i.e. $15-20 \mathrm{~cm}$ and $20-25 \mathrm{~cm}$ ) were not taken into account for the analyses. The total number of polychaete individuals and species found in the assemblages was 5,400 and 76,700 ind. $\mathrm{m}^{-2}$ and 14 and 7 species in Cymodocea and Ruppia meadows, respectively. In terms of abundance, the polychaetes represented about $30 \%$ and $64 \%$ of the total infauna of the Cymodocea and Ruppia meadows, respectively.

When comparing the vertical distribution in the Cymodocea meadow from the Ensenada de los Abades with those of Cymodocea and Ruppia in the Bay of Els Alfacs (Fig. 5), the differences in number of species, abundance and diversity of polychaetes were always significant for the two analysed factors (i.e., meadow and sediment layer) used in the two-way ANOVA (Table 6). However, there were also significant combined effects of both factors, this resulting in different interpretations of the obtained results.

In terms of number of species and diversity, the main responsible of the differences was the 0 $5 \mathrm{~cm}$ sediment layer in the Ensenada de los Abades (Tukey test, $\mathrm{p}<0.0001$ and $\mathrm{p}<0.001$, respectively), which was significantly higher from both the remaining sediment layers in the same locality and from all meadows and layers in the Bay of Els Alfacs (Fig. 5). Additionally, the Tukey test also revealed significant differences in number of species and diversity between the 5$10 \mathrm{~cm}$ and remaining sediment layers in the Ensenada de los Abades. There was, however, a divergence in the results of the Tukey test for the number of species with respect to that based on diversity, as the differences between the $0-5 \mathrm{~cm}$ layer in the two Cymodocea meadows differed in terms of species number (being higher in the Canarian assemblage) and do not differed in terms of diversity.

As for the number of individuals, the Tukey test reveals that the $0-5 \mathrm{~cm}$ layers from the Ensenada de los Abades and from the Ruppia meadow in the Bay of Els Alfacs (Tukey test, $\mathrm{p}<$ 
0.0001 and $\mathrm{p}<0.0003$, respectively) were the responsible of the observed differences by differing both among them (highest abundances in the Ruppia meadow and intermediate in the Canarian Cymodocea meadow) and from all other sediment layers from the two localities (with clearly low abundances) (Fig. 5).

In summary, the differences between the three studied meadows may be attributable to the combination of two different factors. The local differences in species pool when comparing the Ensenada de los Abades with the Bay of Els Alfacs and the differences in the structure of the Cymodocea and Ruppia meadows as habitats for the polychaete assemblage, particularly because the later was mainly inhabited by small, highly abundant opportunistic species which characterize highly disturbed environments.

\section{Discussion}

The structure of the polychaete assemblage inhabiting the $C$. nodosa meadows in the Ensenada de los Abades (Tenerife) was rather uniform throughout the year. Most of the polychaete fauna corresponded to interstitial forms typical from soft bottoms, particularly belonging to the families Syllidae, Paraonidae and Spionidae. The Syllidae was the commonest family of the assemblage, with a higher abundance and species richness during colder months. The most representative species all year round belonged to the subfamilies Eusyllinae, genus Streptosyllis (S. bidentata, $S$. campoyi, S. websteri, S. templadoi) and Exogoninae, genus Exogone (E. parahomoseta mediterranea, E. breviantennata, E. verugera). The Paraonidae were represented mainly by Aricidea assimilis and Cirrophorus perdidoensis. These species also showed maxima in abundance during the colder months and decreased remarkably during the warmer ones, while the species richness was similar along the year. The Spionidae were represented by six species throughout the year, although none of them was clearly dominant in the assemblage. The Capitellidae were more frequent during winter, being Capitomastus minimus the most abundant species, which was a frequent species in soft bottoms covered with vegetation.

The families Syllidae, Capitellidae and Spionidae (Gambi et al. 1998), together with the Paraonidae (Giangrande and Gambi 1986; Lanera and Gambi 1993), have also been considered the most abundant among the polychaete fauna from the foliar and rhizome layers of $C$. nodosa 
and Z. noltii meadows in the Mediterranean. Nevertheless, there are some differences in the dominant species between the assemblages of the Canary Islands and the Mediterranean ones. In the Canary Islands, four species of the genus Streptosyllis are very important, while in the Mediterranean Sea, only S. websteri was present, although scarce, in the assemblage (Gambi et al. 1998). The Nereididae are one of most abundant families in Mediterranean C. nodosa meadows, almost exclusively represented by Neanthes caudata (Gambi et al. 1998). This species, together with Platynereis dumerilii, is also very abundant in different Australian seagrass systems (Hutchings 1982). Conversely, this family has no relevance in the Canarian assemblage, while the Questidae, represented by the interstitial species Periquesta canariensis (which is absent from the Mediterranean) is very important within the $C$. nodosa meadows.

The Canarian assemblage is characterized by a high abundance of larvae and juveniles from a variety of species, belonging either to the macrofauna or to the meiofauna. Again, the larvae of Streptosyllis spp. must be pointed out. These larvae are present in all monthly samples, which indicate a high reproductive potential of the species of this genus in this particular habitat throughout the year. Many other larvae and juvenile stages, belonging to numerous families have also been found. Among them (ordered according to their abundance) we mention the larvae of Paraonidae and Ophelidae, the juveniles of Parapionosyllis (Syllidae), the larvae of Chaetopteridae, Maldanidae, Spionidae and the juveniles of Sabellidae and Syllides (Syllidae). Certainly, the use of fine sieves used in the present study may contribute to explain this remarkable presence of larvae, stressing the relevance of studying the different size range of the infauna to obtain a more complete picture of the temporal trends.

The multivariate analyses point out the existence of a temporal differences in the polychaete assemblage from $C$. nodosa, with two main periods being recognized throughout the year: a longer cold period (i.e., January, February, March, April, May, October, November and December) and a shorter warm period (July, August and September). On the other hand, the assemblage found in June differs both from the assemblages found in summer and winter. As a consequence, it has been considered as a transition assemblage, which was characterized by the high abundance of Schroederella laubieri, the absence of $C$. minimus and the presence of Spiochaetopterus costarum. This pattern with only two clearly distinguishable seasonal periods does not agree with the results obtained in some studies of both Mediterranean (Formentera, Balearic Islands) and Atlantic (Ria de Ferrol, Galicia) polychaete communities, where four 
seasonal periods are usually identified (Besteiro et al. 1990; Soler et al. 1997). However, when considering whole assemblages (including non-vegetated systems, but also Cymodocea and Ruppia meadows), a common seasonal pattern has been proposed for the NW Mediterranean mediolittoral macroinfauna, which is mainly characterized a high abundance (mid-autumn to late spring) and low abundance (early summer to early autumn) seasons (Sardá et al. 1995). Conversely, sublittoral macroinfaunal assemblages differ in having fairly constant annual densities, with maxima from early spring to early summer (Sardá et al. 1995). In both cases, however, the seasonal patterns seem to be mainly connected to reproductive activities of the respective species (Sardá et al. 1995).

The main faunistic descriptors (i.e., density, species richness and diversity) maintain generally a great uniformity throughout the year. The month with a high density, richness and diversity is September, while the lowest density values occurs in May and June and those of richness and diversity in July. Accordingly, the existence of low richness and diversity values during July were also registered in Mediterranean polychaete assemblages associated to C. nodosa (Gambi et al. 1998).

Most of the species inhabiting the rhizomes are also typical from soft bottoms, which also occur in nearby sandy bottoms (Lanera and Gambi 1993). Nevertheless, the presence of the meadow increase the fine particles and organic matter in the sediment, this allowing to maintain a quite homogenous and stable assemblage throughout the year. Moreover, density, species richness and diversity are usually much higher that those of the adjacent sandy zones. Some species inhabiting the assemblage (e.g. Cirrophorus perdidoensis, Parapionosyllis labronica, Schroederella laubieri and Spiochaetopterus costarum) tend to show a patchy distribution, as indicated by the high variability and standard deviation between replicates.

The results of the study of the vertical distribution indicate that the polychaete assemblage of the $C$.nodosa meadows in the Ensenada de los Abades inhabits the sediments to depths of at least $30 \mathrm{~cm}$, although nearly the $90 \%$ occurs within the first $5 \mathrm{~cm}$. In the Bay of Els Alfacs, the polychaetes reached depths of $15 \mathrm{~cm}$, both in the $C$. nodosa and $R$, cirrhosa meadows. However, they were more uniformly distributed in the former (39\% in the first $5 \mathrm{~cm}, 41 \%$ between 5 and 10 $\mathrm{cm}$, and $20 \%$ between 10 and $15 \mathrm{~cm}$ ) than in the latter (more than $90 \%$ within the first $5 \mathrm{~cm}$ ). In the Canarian $C$. nodosa assemblage, the most frequent species inhabiting deep layers of sediment are: C.perdidoensis, A. assimilis, C.minimus, C. armatus, P. canariensis and S. bidentata while, 
in the Mediterranean one they were $M$. fuliginosus, $M$. trinchesi and $C$. furcatus. Conversely, the infauna from the R. cirrhosa meadows is dominated by capitellids (i.e. Capitella spp.) and, particularly, by spionids (i.e. S. shrubsolii). In the Canarian assemblage, no remarkable seasonal differences in abundance of polychaetes at the different depth layers have been observed, although an increase in the number of specimens in deep layers during some punctual periods with high hydrodynamics has been observed.

In environments characterized by silty-sand sediments, the fauna tends to inhabit mainly the first $2 \mathrm{~cm}$ of sediment (Cruz and Vargas 1987), largely because of the lack of oxygen and the degree of compaction. Similar results have been obtained for the Mediterranean polychaete fauna, where an $84 \%$ inhabited the first $5 \mathrm{~cm}$ of the sediment in $C$. nodosa meadows (Gambi et al. 1998) and the first $4 \mathrm{~cm}$ in Posidonia oceanica meadows (Willsie 1983; Somaschini et al. 1994). The results obtained at the $R$. cirrhosa meadow from the Bay of Els Alfacs confirm this trend. As the sediments are highly compacted, have high organic matter and fine sediment contents, and low Redox potential, the associated infauna is mainly composed by small, numerous opportunistic species such as Capitella spp. and Streblospio shrubsolii (Palacín et al. 1991; Martin et al. 1993, 2000). Conversely, the C. nodosa meadows from the Bay of Els Alfacs clearly differ, as the polychaetes were more or less uniformly distributed along the first $15 \mathrm{~cm}$ of sediment. This was likely connected to the low fine sediment contents, the high oxygenation and the low compactness of the sediments and, thus, to a polychaete assemblage dominated by species characteristic of biologically controlled assemblages (sensu Sanders 1969) such as those of the genera Mastobranchus, Phylo or Neanthes (Palacín et al. 1991; Martin et al. 1993, 2000).

Cymodocea nodosa and Ruppia cirrhosa do not have a highly architectural complexity within the sediment, as it happens, for instance, with Posidonia oceanica, which usually modifies the structure of the bottoms so that the type of sediment have a less important influence on the associated assemblages when compared with the plant. In contrast, our results support that, besides the biogeographical variability in the infaunal polychaete species pool inhabiting a given small-sized seagrass meadow, the structural characteristics of the assemblages appeared to be more strongly controlled by the characteristics of the sediment than by the seagrass species building the meadow. Is should be taken into account, however, that in addition to the structure of the rhizomes, other factors such as the seagrass density or the way how each seagrass species 
modify the water flow inside the meadow can affect the sediment characteristics, and this seems certainly be the case of Cymodocea and Ruppia.

\section{References}

Alfonso-Carrillo J, Gil-Rodríguez MC (1980) Cymodocea nodosa (Ucria) Ascherson (Zannichelliaceae) y las praderas submarinas o sebadales de las Islas Canarias. Vieraea 8: 365-376

Allison LE, Moodie CD (1965) Carbonate. In: Black CA (ed) Methods of Soil Analysis. American Society of Agronomy, Madison, WI, pp 1389-1392

Alós C (1988) Anélidos poliquetos de Cabo de Creus (Alt Empordà). Doctoral Thesis, Universitat de Barcelona

Besteiro C, Urgorri V, Parapar J (1990) Estratificación vertical y variación temporal de la fauna mesopsámmica de arenas de Amphioxus en la ría de Ferrol (Galicia). Thalassas 8: 107-115

Bilyard GR (1987) The value of benthic infauna in marine pollution studies. Mar Poll Bull 18: 581-585

Bloom SA, Simon JL, Hunter VD (1972) Animal-sediment relations and community analysis of a Florida estuary. Mar Biol 15: 43-56

Bray JR, Curtis CT (1957) An ordination of the upland forest communities of southern Wisconsin. Ecol Monogr 27: 325-349

Brito MC, Núñez J (2002) A new genus and species of Questidae (Annelida: Polychaeta) from the Central Macaronesia Region and a cladistic analysis of the family. Sarsia 87: 281-289

Brito MC, Núñez J, San Martín G (2000a) The Genus Streptosyllis Webster and Benedict,1884 (Polychaeta: Syllidae: Eusyllinae) from the Canary Islands, with description of a new species. Bull Mar Sci 67: 603-615

Brito MC, Núñez J, San Martín G (2000b) Parapionosyllis macaronesiensis, a new species of Exogoninae (Polychaeta: Syllidae) from the Macaronesian Region. Proc Biol Soc Wash 113: 1147-1150

Brito MC, Núñez J, San Martín G (2001) Sílidos (Annelida: Polychaeta) intersticiales asociados a praderas de Cymodocea nodosa de las Islas Canarias. Avicennia 14: 85-100

Buchanan JB (1984) Sediment analysis. In: Holme NA, McIntyre AD (eds) Methods for the study of marine benthos. Blackwell Scientific Publications, Oxford, pp 41-65

Buchanan JB, Kain JM (1971) Measurement of the physical and chemical environment. In: Holme NA, McIntyre AD (eds) Methods for the study of marine benthos. Blackwell Scientific Publications, Oxford, pp 30-52

Buia MC, Russo GF, Mazzella L (1985) Interrelazioni tra Cymodocea nodosa (Ucria) Aschers. e Zostera noltii Hornem in un prato misto superficiale dell'isola d'Ischia. Nova Thalas 7 suppl. 3: 406-408

Camp J, Romero J, Pérez M, Vidal M, Delgado M, Martínez A (1991) Production-consumption budget in an estuarine bay: How anoxia is prevented in a forced system. Oecol Aquat 10: 145-152

Clarke KR (1993) Non-parametric multivariate analyses of changes in assemblage structure. Aust J Ecol 18: 117143

Clarke KR, Warwick RM (1994) Change in marine community: An approach to statistical analysis and interpretation. Plymouth Marine Laboratory, Plymouth 
Colognola R, Gambi MC, Chessa LA (1984) Polychaetes of Posidonia oceanica (L.) Delile foliar stratum: comparative observation. In: Boudouresque CF, Jeudy de Grissac A, Olivier J (eds) Proceedings of the first International workshop on Posidonia oceanica beds. GIS Posidonia publ Fr 1: 101-108

Cruz E, Vargas JA (1987) Abundancia y distribución vertical de la meiofauna en la playa fangosa de Punta Morales, Golfo de Nicoya, Costa Rica. Rev Biol Trop 35: 363-367

Gambi MC, Giangrande A, Martilelli M, Chessa LA (1995) Polychaetes of a Posidonia oceanica bed off Sardinia (Italy): spatial and seasonal distribution and feeding guild analysis. Sci Mar 59: 129-141

Gambi MC, Conti G, Bremec CS (1998) Polychaete distribution, diversity and seasonality related to seagrass cover in shallow soft botoms of the Tyrrhenian Sea (Italy). Sci Mar 62: 1-17

Giangrande A, Gambi MC (1986) Polychètes d’une pelouse a Cymodocea nodosa (Ucria) Aschers. du Golfe de Salerno (Mer Tyrrhénienne). Vie Milieu 36: 185-190

Howard RK, Edgar GJ, Hutchings PA (1989) Faunal assemblages of seagrass beds. In: Larkum AWD, McComb AJ, Shepherd SA (eds) Biology of seagrasses: a treatise on the biology of seagrasses with special reference to the Australian region. Elsevier, Amsterdam, pp 536-564

Hutchings PA (1982) The fauna of Australian seagrass beds. Proc Linn Soc NSW 106: 181-200

Jackson ML (1960) Soil chemical analysis. Prentice Hall, New York

Kikuchi T (1980) Faunal relationships in temperate seagrass beds. In: Phillips RC, McRoy CP (eds) Handbook of seagrass biology: an ecosystem perspective. Garland STPM Press, New York, pp 153-172

Lanera P, Gambi MC (1993) Polychaete distribution in some Cymodocea nodosa meadows around the Island of Ischia (Gulf of Naples Italy). Oebalia 19: 89-103

Marr IL, Cresser MS, Gómez Ariza JL (1990) Química analítica del medio ambiente. Servicio de Publicaciones Universidad de Sevilla, Sevilla

Martin D, Ballesteros E, Gili JM, Palacín C (1993) Small-scale structure of infaunal polychaete communities in an estuarine environment: Methodological approach. Estuar Coast Shelf Sci 36: 47-58

Martin D, Pinedo S, Sardá R (2000) Distribution patterns and trophic structure of soft-bottom Polychaete assemblages in a North-Western Mediterranean shallow-water Bay. Ophelia 53: 1-17

Molinier R, Picard J (1952) Recherches sur les herbiers de phanérogames marines du littoral méditerranéen français. Ann Inst Océanogr Paris NS 27: 157-234

Palacín C, Martin D, Gili JM (1991) Features of spatial distribution of benthic infauna in a Mediterranean shallowwater bay. Mar Biol 110: 315-321

Pielou EC (1969) An introduction to mathematical ecology. Willey, New York

Reyes J (1993) Estudio de las praderas marinas de Cymodocea nodosa (Cymodoceaceae, Magnoliophyta) y su comunidad de epífitos, en el Médano (Tenerife, Islas Canarias). Doctoral Thesis, Universidad de La Laguna

Rizzo AE, Amaral ACZ (2000) Temporal variation of annelids in the intertidal zone of beaches of the São Sebastião Channel, southern Brazil. J Mar Biol Assoc UK 80: 1007-1017

Sanders HL (1969) Benthic marine diversity and the stability-time hypothesis. Brookhaven Symp Biol 22: 71-80 
Sardá R, Martin D, Pinedo S, Dueso A, Cardell MJ (1995) Seasonal dynamics of shallow-water benthic communities in the Western Mediterranean. In: Nicolaidou A (ed) The biology and ecology of shallow coastal waters. Olssen \& Olssen, Fredensborg, pp 191-198

Shannon CE, Weaver W (1949) The mathematical theory of communication. Illinois University Press, Urbana

Soler A, Ballesteros M, Turón X (1997) Poliquetos el Estany des Peix (Formentera, Baleares). Aproximación al estudo faunístico y ecológico. Hist animal 3: 9-23

Somaschini A, Gravina MF, Ardizzone GD (1994) Polychete depth distribution in a Posidonia oceanica bed (rhizome and matte strata) and neighbouring soft and hard bottoms. PSZN I: Mar Ecol 15: 133-151

Soyer J (1970) Bionomie benthique du plateau continental de la côte catalane française. III. Les peuplements de Copépodes Harpacticoides (Crustacea). Vie Milieu 21: 337-511

Terlizzi A, Russo GF (1998) The molluscan taxocoene of different-exposed Cymodocea nodosa beds: year-long structural patterns and sampling methods. Boll Malacologico 33: 77-82

True-Schlenz R (1965) Données sur les peuplements des sédiments a petites phanérogames marines (Zoostera nana Roth et Cymodocea nodosa Ascherson) comparés a ceux des habitats voisins dépourvus de végétation. Rec Trav St Mar Endoume 39: 96-125

Walkey A (1947) A critical examination of a rapid method for determining organic carbon in soil. Soil Science 63: $251-263$

Whitlatch RB (1977) Seasonal changes in the community structure of the macrobenthos inhabiting the intertidal sand and mud flats of Barnstable Harbor, Massachusetts. Biol Bull 152: 275-294

Willsie A (1983) Zonation de la macrofaune endogée de la matte d’herbiers de Posidonia oceanica (L.) Delile. Rapp Comm Int Mer Medit 28: 165-168

Young DK, Young MW (1977) Assemblage structure of the macrobenthos associated with seagrasses of the Indian River Estuary, Florida. In: Coull BC (ed) Ecology of Marine Benthos. Belle W. Baruch Institute for Marine Biology; University of South Carolina Press, Columbia, S.C.; Columbia, S.C., pp 339-381

Zar JH (1984) Biostatistical Analysis. Prentice Hall International, New Jersey 
Table 1 Polychaete species found during the annual survey at the Ensenada de los Abades. NS: number of samples; FREQ: frequency (C: constant; A: accessory; a: accidental), NUMB: number of specimens (Ind. $\cdot \mathrm{m}^{-2}$ ), STD: standard deviation, N IND: total number of specimens, DOM: Soyer's dominance (D: dominant).

\begin{tabular}{|c|c|c|c|c|c|c|c|c|}
\hline POLYCHAETE SPECIES & NS & FR & & NUMB & STD & N IND & DOM & \\
\hline $\begin{array}{l}\text { Streptosyllis bidentata Southern, } 1914 \\
\end{array}$ & 33 & 68.8 & $\mathrm{C}$ & 2.565 & 11.0 & 197 & 16.9 & $\mathrm{D}$ \\
\hline Aricidea assimilis Tebble, 1959 & 36 & 75.0 & $\mathrm{C}$ & 2.070 & 11.5 & 159 & 13.6 & $\mathrm{D}$ \\
\hline Exogone parahomoseta mediterranea San Martín, 1984 & 26 & 54.2 & $\mathrm{C}$ & 1.970 & 9.0 & 149 & 12.8 & $\mathrm{D}$ \\
\hline Cirrophorus perdidoensis McLelland \& Gaston, 1994 & 18 & 37.5 & A & 1.667 & 8.4 & 128 & 11.0 & $\mathrm{D}$ \\
\hline Streptosyllis campoyi Brito, Núñez \& San Martín, 2000 & 18 & 37.5 & A & 964 & 6.1 & 74 & 6.3 & $\mathrm{D}$ \\
\hline Periquesta canariensis Brito \& Núñez, 2002 & 17 & 35.4 & A & 677 & 5.6 & 52 & 4.5 & $\mathrm{D}$ \\
\hline Exogone breviantennata Hartmann-Schröeder, 1959 & 17 & 35.4 & A & 586 & 5.7 & 45 & 3.9 & $\mathrm{D}$ \\
\hline Streptosyllis websteri Southern, 1914 & 13 & 27.1 & A & 521 & 4.5 & 40 & 3.4 & $\mathrm{D}$ \\
\hline Capitomastus minimus (Langerhans, 1880) & 20 & 41.7 & A & 443 & 6.4 & 34 & 2.9 & $\mathrm{D}$ \\
\hline Streptosyllis templadoi San Martín, 1984 & 13 & 27.1 & A & 260 & 4.2 & 22 & 1.9 & $\mathrm{D}$ \\
\hline Parapionosyllis labronica Cognetti, 1965 & 5 & 10.4 & a & 247 & 2.2 & 19 & 1.6 & $\mathrm{D}$ \\
\hline Exogone verugera (Claparède, 1868$)$ & 12 & 25.0 & A & 234 & 3.9 & 18 & 1.5 & $\mathrm{D}$ \\
\hline Larvae of Streptosyllis & 6 & 12.5 & a & 221 & 2.1 & 17 & 1.5 & $\mathrm{D}$ \\
\hline Schroederella laubieri Badalamenti \& Castelli, 1991 & 7 & 14.6 & a & 195 & 2.4 & 15 & 1.3 & $\mathrm{D}$ \\
\hline Cirrophorus armatus (Glémarec, 1966) & 9 & 18.8 & a & 182 & 2.9 & 14 & 1.2 & $\mathrm{D}$ \\
\hline Spiochaetopterus costarum (Claparède, 1868) & 4 & 8.3 & $\mathrm{a}$ & 156 & 1.6 & 12 & 1.0 & $\mathrm{D}$ \\
\hline Microspio mecznikovianus (Claparède, 1869) & 6 & 12.5 & a & 143 & 2.0 & 11 & 0.9 & \\
\hline Poecilochaetus serpens Allen, 1904 & 7 & 14.6 & a & 130 & 2.3 & 10 & 0.9 & \\
\hline Salvatoria clavata (Claparède, 1863) & 5 & 10.4 & a & 117 & 1.7 & 9 & 0.8 & \\
\hline Hesionura elongata Southern, 1914 & 4 & 8.3 & a & 117 & 1.5 & 9 & 0.8 & \\
\hline Ophelia bicornis Savigny, 1818 & 5 & 10.4 & $\mathrm{a}$ & 104 & 1.7 & 8 & 0.7 & \\
\hline Travisia forbesii Johnston, 1840 & 2 & 4.2 & $\mathrm{a}$ & 104 & 1.2 & 8 & 0.7 & \\
\hline Larvae of Paraonidae & 1 & 2.1 & $\mathrm{a}$ & 78 & 0.9 & 6 & 0.5 & \\
\hline Pseudofabriciola $\mathrm{n} . \mathrm{sp}$ & 4 & 8.3 & a & 78 & 1.3 & 6 & 0.5 & \\
\hline Spirobranchus polytrema (Phillippi, 1844) & 2 & 4.2 & a & 78 & 0.9 & 6 & 0.5 & \\
\hline Larvae of Ophelidae & 2 & 4.2 & a & 65 & 0.8 & 5 & 0.4 & \\
\hline Erinaceusyllis cryptica (Ben-Eliahu, 1977) & 3 & 6.3 & $\mathrm{a}$ & 65 & 1.0 & 5 & 0.4 & \\
\hline Anoplosyllis edentula (Claparède, 1868) & 2 & 4.2 & a & 65 & 0.8 & 5 & 0.4 & \\
\hline Syllides japonicus Imajima, 1966 & 3 & 6.3 & a & 65 & 1.0 & 5 & 0.4 & \\
\hline Caulleriella bioculata (Keferstein, 1862) & 2 & 4.2 & a & 52 & 0.8 & 4 & 0.3 & \\
\hline Polyophtalmus pictus (Dujardin, 1839) & 2 & 4.2 & a & 52 & 0.8 & 4 & 0.3 & \\
\hline Prionospio steenstrupi Malmgren, 1867 & 3 & 6.3 & a & 52 & 1.0 & 4 & 0.3 & \\
\hline Spio decoratus Bobretzky, 1871 & 2 & 4.2 & $\mathrm{a}$ & 52 & 0.8 & 4 & 0.3 & \\
\hline Scolaricia $\mathrm{sp}$ & 4 & 8.3 & a & 52 & 1.3 & 4 & 0.3 & \\
\hline Aricidea cerruti Laubier, 1966 & 2 & 4.2 & a & 39 & 0.7 & 3 & 0.3 & \\
\hline Armandia intermedia Fauvel, 1902 & 2 & 4.2 & a & 39 & 0.7 & 3 & 0.3 & \\
\hline Aonides oxycephala (Sars, 1864) & 2 & 4.2 & a & 39 & 0.7 & 3 & 0.3 & \\
\hline Dispio uncinata Hartman, 1951 & 3 & 6.3 & a & 39 & 1.0 & 3 & 0.3 & \\
\hline Nematonereis unicornis Schmarda, 1861 & 3 & 6.3 & a & 39 & 1.0 & 3 & 0.3 & \\
\hline Ophryotrocha paragerlachi Brito \& Núñez, 2003 & 2 & 4.2 & a & 39 & 0.7 & 3 & 0.3 & \\
\hline Schistomeringos albomaculata Åkesson \& Rice, 1992 & 2 & 4.2 & a & 39 & 0.7 & 3 & 0.3 & \\
\hline Sigalion mathildae Audouin \& M. Edwards, 1832 & 3 & 6.3 & a & 39 & 1.0 & 3 & 0.3 & \\
\hline Juveniles of Parapionosyllis & 2 & 4.2 & a & 26 & 0.7 & 2 & 0.2 & \\
\hline Larvae of Chaetopteridae & 1 & 2.1 & a & 26 & 0.4 & 2 & 0.2 & \\
\hline Larvae of Maldanidae & 2 & 4.2 & a & 26 & 0.7 & 2 & 0.2 & \\
\hline Larvae of Spionidae & 1 & 2.1 & a & 26 & 0.4 & 2 & 0.2 & \\
\hline Parapionosyllis macaronensis Brito, Núñez \& San Martín, 2000 & 2 & 4.2 & a & 26 & 0.7 & 2 & 0.2 & \\
\hline Pionosyllis spinisetosa San Martín, 1990 & 2 & 4.2 & a & 26 & 0.7 & 2 & 0.2 & \\
\hline Armandia cirrhosa Phillippi, 1865 & 1 & 2.1 & $\mathrm{a}$ & 13 & 0.3 & 1 & 0.1 & \\
\hline Capitella capitata (Fabricius, 1780) & 1 & 2.1 & $\mathrm{a}$ & 13 & 0.3 & 1 & 0.1 & \\
\hline
\end{tabular}


Table 1 (Contd.)

\begin{tabular}{|c|c|c|c|c|c|c|c|}
\hline POLYCHAETE SPECIES & NS & FREQ & & IND $\cdot \mathbf{m}^{-2}$ & STD & N IND & DOM \\
\hline Clymenura clypeata (Saint-Joseph, 1894) & 2 & 4.2 & $\mathrm{a}$ & 13 & 0.7 & 1 & 0.1 \\
\hline Cirrophorus ilvana (Castelli, 1985) & 1 & 2.1 & a & 13 & 0.3 & 1 & 0.1 \\
\hline Fauveliopsis sp. & 1 & 2.1 & a & 13 & 0.3 & 1 & 0.1 \\
\hline Salvatoria neapolitana (Goodrich, 1930) & 1 & 2.1 & a & 13 & 0.3 & 1 & 0.1 \\
\hline Salvatoria vieitezi (San Martín, 1984) & 1 & 2.1 & a & 13 & 0.3 & 1 & 0.1 \\
\hline Aponuphis bilineata (Marenzeller, 1886) & 1 & 2.1 & a & 13 & 0.3 & 1 & 0.1 \\
\hline Malmgreniella lunulata (Delle Chiaje, 1841) & 1 & 2.1 & a & 13 & 0.3 & 1 & 0.1 \\
\hline Juveniles of Sabellidae & 1 & 2.1 & a & 13 & 0.3 & 1 & 0.1 \\
\hline Juveniles of Syllides & 1 & 2.1 & a & 13 & 0.3 & 1 & 0.1 \\
\hline Lepidonotus cf. carinulatus Grube, 1870 & 1 & 2.1 & a & 13 & 0.3 & 1 & 0.1 \\
\hline Notomastus latericeus Sars, 1851 & 1 & 2.1 & a & 13 & 0.3 & 1 & 0.1 \\
\hline Nerilidium mediterraneum Remane, 1928 & 1 & 2.1 & a & 13 & 0.3 & 1 & 0.1 \\
\hline Prionospio cirrifera Wiren, 1883 & 1 & 2.1 & a & 13 & 0.3 & 1 & 0.1 \\
\hline Platynereis dumerilii (Audouin \& M. Edwards, 1833) & 1 & 2.1 & a & 13 & 0.3 & 1 & 0.1 \\
\hline Pisione guanche San Martín, López \& Núñez, 1999 & 1 & 2.1 & a & 13 & 0.3 & 1 & 0.1 \\
\hline Questa caudicirra Hartman, 1966 & 1 & 2.1 & a & 13 & 0.3 & 1 & 0.1 \\
\hline Syllidia armata Quatrefages, 1865 & 1 & 2.1 & a & 13 & 0.3 & 1 & 0.1 \\
\hline Scolelepis lefebrei (Gravier, 1905) & 1 & 2.1 & $\mathrm{a}$ & 13 & 0.3 & 1 & 0.1 \\
\hline
\end{tabular}


Table 2 Mean abundances of the species with greater similarity between all the groups obtained in the multivariate analyses according to the SIMPER routine.

\begin{tabular}{|c|c|c|c|c|c|c|c|c|}
\hline \multirow{2}{*}{$\begin{array}{l}\text { MULTIVARIATE GROUPS } \\
\text { Responsible species }\end{array}$} & \multicolumn{2}{|c|}{ I } & \multicolumn{2}{|c|}{ II } & \multicolumn{2}{|c|}{ III } & \multicolumn{2}{|c|}{ IV } \\
\hline & Ind. $\cdot \mathbf{m}^{-2}$ & std & Ind. $\cdot \mathbf{m}^{-2}$ & std & Ind. $\cdot \mathbf{m}^{-2}$ & std & Ind. $\cdot \mathbf{m}^{-2}$ & std \\
\hline Streptosyllis bidentata & 72.02 & 78.13 & 37.96 & 57.46 & 32.5 & 24.83 & 30.94 & 29.38 \\
\hline Aricidea assimilis & 52.52 & 57.07 & 20. & 25.74 & 26 & 10.66 & 56.94 & 33.28 \\
\hline Exogone parahomoseta mediterranea & 40.04 & 63.96 & 75.79 & 68.77 & 9.75 & 19.5 & 3.25 & 9.23 \\
\hline Cirrophorus perdidoensis & 57.98 & 118.95 & 23.79 & 31.33 & 0 & 0 & 0 & 0 \\
\hline Periquesta canariensis & 5.46 & 10.14 & 35.75 & 39.26 & 0 & 0 & 14.69 & 32.11 \\
\hline Exogone verugera & 1.69 & 4.42 & 2.21 & 5.07 & 6.5 & 7.54 & 17.94 & 21.97 \\
\hline
\end{tabular}


Table 3 Results of the one-way ANOVA used to analyse the temporal patterns of the main biological descriptors of the polychaete assemblages from the Cymodocea meadow in the Ensenada de los Abades, using months as a factor. DF: degrees of freedom.

\begin{tabular}{|c|c|c|c|c|c|}
\hline Number of species & Sum-of-squares & DF & Mean-square & F-ratio & $\mathbf{P}$ \\
\hline Months & 2491.63 & 11 & 226.51 & 1.24 & 0.30 \\
\hline Error & 6599.38 & 36 & 183.32 & & \\
\hline \multicolumn{6}{|l|}{ Abundance } \\
\hline Months & 3799.00 & 11 & 345.36 & 2.30 & 0.03 \\
\hline Error & 5395.50 & 36 & 149.88 & & \\
\hline \multicolumn{6}{|l|}{ Species Richness } \\
\hline Months & 2758.63 & 11 & 250.78 & 1.40 & 0.22 \\
\hline Error & 6452.38 & 36 & 179.23 & & \\
\hline \multicolumn{6}{|l|}{ Eveness } \\
\hline Months & 4501.13 & 11 & 409.19 & 3.14 & 0.005 \\
\hline Error & 4684.88 & 36 & 130.14 & & \\
\hline \multicolumn{6}{|l|}{ Diversity } \\
\hline Months & 3101.13 & 11 & 281.92 & 1.66 & 0.12 \\
\hline Error & 6107.88 & 36 & 169.66 & & \\
\hline \multicolumn{6}{|l|}{ Dominance } \\
\hline Months & 3870.88 & 11 & 351.90 & 2.41 & 0.02 \\
\hline Error & 5259.63 & 36 & 146.10 & & \\
\hline
\end{tabular}


Table 4 Vertical distribution of polychaete abundances (ind. $\cdot \mathrm{m}^{-2}$ ) from the Cymodocea meadow at the Ensenada de los Abades.

\begin{tabular}{|c|c|c|c|c|c|c|c|c|}
\hline POLYCHAETE SPECIES & $0-5$ & std & $5-10$ & std & $10-20$ & std & $20-30$ & std \\
\hline Streptosyllis bidentata & 209.0 & 144.4 & 5.5 & 13.0 & 0 & 0 & 0 & 0 \\
\hline Aricidea assimilis & 140.8 & 115.1 & 29.3 & 36.4 & 2.2 & 7.5 & 0 & 0 \\
\hline Exogone parahomoseta mediterrane & 158.2 & 142.2 & 3.3 & 11.3 & 0 & 0 & 0 & 0 \\
\hline Cirrophorus perdidoensis & 107.3 & 169.3 & 30.3 & 35.6 & 2.2 & 5.1 & 0 & 0 \\
\hline Streptosyllis campoy & 69.3 & 60.8 & 10.8 & 26.5 & 0 & 0 & 0 & 0 \\
\hline Periquesta canariensis & 41.2 & 42.1 & 15.2 & 24.1 & 0 & 0 & 0 & 0 \\
\hline Exogone breviantennata & 46.5 & 59.0 & 2.2 & 7.5 & 0 & 0 & 0 & 0 \\
\hline Streptosyllis websteri & 45.5 & 51.6 & 0.0 & 0.0 & 0 & 0 & 0 & 0 \\
\hline Capitomastus minimus & 31.5 & 31.6 & 5.5 & 10.3 & 0 & 0 & 0 & 0 \\
\hline Streptosyllis templadoi & 21.7 & 20.3 & 1.0 & 3.8 & 0 & 0 & 0 & 0 \\
\hline Parapionosyllis labronica & 20.5 & 41.0 & 0.0 & 0.0 & 0 & 0 & 0 & 0 \\
\hline Exogone verugera & 17.3 & 25.0 & 1.0 & 3.8 & 1.0 & 3.8 & 0 & 0 \\
\hline Larvae of Streptosyllis & 16.3 & 20.8 & 1.0 & 3.8 & 0 & 0 & 0 & 0 \\
\hline Schroederella laubieri & 16.3 & 30.4 & 1.0 & 3.8 & 0 & 0 & 0 & 0 \\
\hline Cirrophorus armatus & 12.0 & 13.0 & 2.2 & 7.5 & 4.3 & 14.9 & 0 & 0 \\
\hline Spiochaetopterus costarum & 13.0 & 28.9 & 0 & 0 & 0 & 0 & 0 & 0 \\
\hline Microspio mecznikovianus & 10.8 & 20.7 & 1.0 & 3.8 & 0 & 0 & 0 & 0 \\
\hline Poecilochaetus serpens & 9.8 & 13.8 & 0 & 0 & 1.0 & 3.8 & 0 & 0 \\
\hline Salvatoria clavata & 9.8 & 19.2 & 0 & 0 & 0 & 0 & 0 & 0 \\
\hline Hesionura elongata & 9.8 & 22.9 & 0 & 0 & 0 & 0 & 0 & 0 \\
\hline Ophelia bicornis & 8.7 & 16.0 & 0 & 0 & 0 & 0 & 0 & 0 \\
\hline Travisia forbesii & 8.7 & 26.3 & 0 & 0 & 0 & 0 & 0 & 0 \\
\hline Pseudofabriciola sp. & 6.5 & 13.0 & 0 & 0 & 0 & 0 & 0 & 0 \\
\hline Spirobranchus polytrema & 1.0 & 3.8 & 0 & 0 & 2.2 & 7.5 & 3.3 & 11.3 \\
\hline Larvae of Ophelidae & 5.5 & 18.7 & 0 & 0 & 0 & 0 & 0 & 0 \\
\hline Sphaerosyllis cryptica & 5.5 & 15.1 & 0 & 0 & 0 & 0 & 0 & 0 \\
\hline Syllides edentulus & 5.5 & 15.1 & 0 & 0 & 0 & 0 & 0 & 0 \\
\hline Syllides japonicus & 3.3 & 8.1 & 2.2 & 5.1 & 0 & 0 & 0 & 0 \\
\hline Caulleriella bioculata & 4.3 & 11.6 & 0 & 0 & 0 & 0 & 0 & 0 \\
\hline Polyophtalmus pictus & 1.0 & 3.8 & 0 & 0 & 0 & 0 & 3.3 & 11.3 \\
\hline Prionospio steenstrupi & 4.3 & 8.5 & 0 & 0 & 0 & 0 & 0 & 0 \\
\hline Scolaricia $\mathrm{sp}$ & 4.3 & 8.5 & 0 & 0 & 0 & 0 & 0 & 0 \\
\hline Spio decoratus & 4.3 & 11.6 & 0 & 0 & 0 & 0 & 0 & 0 \\
\hline Aonides oxycephala & 3.3 & 11.3 & 0 & 0 & 0 & 0 & 0 & 0 \\
\hline Aricidea cerruti & 3.3 & 11.3 & 0 & 0 & 0 & 0 & 0 & 0 \\
\hline Armandia intermedia & 3.3 & 11.3 & 0 & 0 & 0 & 0 & 0 & 0 \\
\hline Dispio uncinata & 1.0 & 3.8 & 2.2 & 5.1 & 0 & 0 & 0 & 0 \\
\hline Larvae of Paraonidae & 3.3 & 11.3 & 0 & 0 & 0 & 0 & 0 & 0 \\
\hline Nematonereis unicornis & 3.3 & 5.9 & 0 & 0 & 0 & 0 & 0 & 0 \\
\hline Ophryotrocha paragerlachi & 3.3 & 8.1 & 0 & 0 & 0 & 0 & 0 & 0 \\
\hline Schistomeringos albomaculata & 3.3 & 8.1 & 0 & 0 & 0 & 0 & 0 & 0 \\
\hline Sigalion mathildae & 2.2 & 7.5 & 1.0 & 3.1 & 0 & 0 & 0 & 0 \\
\hline Juveniles of Parapionosyllis & 2.2 & 5.1 & 0 & 0 & 0 & 0 & 0 & 0 \\
\hline Larvae of Chaetopteridae & 2.2 & 7.5 & 0 & 0 & 0 & 0 & 0 & 0 \\
\hline Larvae of Spionidae & 2.2 & 7.5 & 0 & 0 & 0 & 0 & 0 & 0 \\
\hline Parapionosyllis macaronesiensis & 2.2 & 7.5 & 0 & 0 & 0 & 0 & 0 & 0 \\
\hline
\end{tabular}


Table 4 (Contd.)

\begin{tabular}{lcccccccc}
\hline POLYCHAETE SPECIES & $\mathbf{0 - 5}$ & std & $\mathbf{5 - 1 0}$ & std & $\mathbf{1 0 - 2 0}$ & std & $\mathbf{2 0 - 3 0}$ & std \\
\hline Armandia cirrhosa & 1.0 & 3.8 & 0 & 0 & 0 & 0 & 0 & 0 \\
Capitela capitata & 1.0 & 3.8 & 0 & 0 & 0 & 0 & 0 & 0 \\
Cirrophorus ilvana & 1.0 & 3.8 & 0 & 0 & 0 & 0 & 0 & 0 \\
Clymenura clypeata & 1.0 & 3.8 & 0 & 0 & 0 & 0 & 0 & 0 \\
Fauveliopsis sp. & 1.0 & 3.8 & 0 & 0 & 0 & 0 & 0 & 0 \\
Salvatoria neapolitana & 1.0 & 3.8 & 0 & 0 & 0 & 0 & 0 & 0 \\
Salvatoria vieitezi & 0 & 0 & 0 & 0 & 0 & 0 & 1.0 & 3.8 \\
Harmothoe lunulata & 1.0 & 3.8 & 0 & 0 & 0 & 0 & 0 & 0 \\
Aponuphis bilineata & 1.0 & 3.8 & 0 & 0 & 0 & 0 & 0 & 0 \\
Juveniles of Syllides & 1.0 & 3.8 & 0 & 0 & 0 & 0 & 0 & 0 \\
Larvae Maldanidae & 1.0 & 3.8 & 0 & 0 & 0 & 0 & 0 & 0 \\
Lepidonotus cf.carinulatus & 0 & 0 & 0 & 0 & 1.0 & 3.8 & 0 & 0 \\
Nerilidium mediterraneum & 1.0 & 3.8 & 0 & 0 & 0 & 0 & 0 & 0 \\
Notomastus latericius & 0 & 0 & 0 & 0 & 1.0 & 3.8 & 0 & 0 \\
Pisione guanche & 1.0 & 3.8 & 0 & 0 & 0 & 0 & 0 & 0 \\
Platynereis dumerilii & 1.0 & 3.8 & 0 & 0 & 0 & 0 & 0 & 0 \\
Prionospio cirrifera & 1.0 & 3.8 & 0 & 0 & 0 & 0 & 0 & 0 \\
Questa caudicirra & 1.0 & 3.8 & 0 & 0 & 0 & 0 & 0 & 0 \\
Syllidia armata & 0 & 0 & 0 & 0 & 1.0 & 3.8 & 0 & 0 \\
Pionosyllis spinisetosa & 1.0 & 3.8 & 1.0 & 3.8 & 0 & 0 & 0 & 0 \\
\hline
\end{tabular}


Table 5 Vertical distribution of mean polychaete abundances (ind. $\cdot \mathrm{m}^{-2}$ ) from Cymodocea and Ruppia meadows at the Bay of Els Alfacs. Sediment layers are indicated as intervals of $5 \mathrm{~cm}$ except from 15 to $25 \mathrm{~cm}$ deep, which are not included as polychaetes were absent.

\begin{tabular}{|c|c|c|c|c|c|c|c|c|c|c|c|c|}
\hline \multirow[b]{2}{*}{ POLYCHAETE ESPECIES } & \multicolumn{6}{|c|}{ Cymodocea } & \multicolumn{6}{|c|}{ Ruppia } \\
\hline & $0-5$ & std & $5-10$ & std & $10-15$ & std & $0-5$ & std & $5-10$ & std & $10-15$ & std \\
\hline Capitella capitata (Fabricius, 1780) & 0 & 0 & 0 & 0 & 0 & 0 & 475 & 427.2 & 0 & 0 & 0 & 0 \\
\hline Heteromastus filiformis (Claparède, 1864) & 0 & 0 & 50 & 100 & 0 & 0 & 50 & 57.7 & 100 & 141.4 & 25 & 50 \\
\hline Mastobranchus trinchesi Eisig, 1887 & 125 & 150 & 175 & 236.3 & 125 & 189.3 & 0 & 0 & 0 & 0 & 0 & 0 \\
\hline Notomastus latericeus M. Sars, 1851 & 0 & 0 & 0 & 0 & 25 & 50 & 0 & 0 & 25 & 50 & 0 & 0 \\
\hline Caulleriella caputesocis (Saint-Joseph, 1894) & 0 & 0 & 0 & 0 & 0 & 0 & 25 & 50 & 0 & 0 & 0 & 0 \\
\hline Glycera trydactila Schmarda, 1861 & 0 & 0 & 25 & 50 & 0 & 0 & 0 & 0 & 0 & 0 & 0 & 0 \\
\hline Clymenura clypeata (Sain-Joseph, 1894) & 0 & 0 & 50 & 100 & 25 & 50 & 0 & 0 & 0 & 0 & 0 & 0 \\
\hline Hediste diversicolor (O.F. Müller, 1776) & 0 & 0 & 0 & 0 & 0 & 0 & 25 & 50 & 0 & 0 & 50 & 57.7 \\
\hline Neanthes caudata (Delle Chiaje, 1828) & 75 & 95.7 & 0 & 0 & 0 & 0 & 0 & 0 & 0 & 0 & 0 & 0 \\
\hline Phylo foetidus adjimenis (Fauvel, 1925) & 25 & 50 & 50 & 57.7 & 25 & 50 & 0 & 0 & 0 & 0 & 0 & 0 \\
\hline Phylo norvergica (Sars, 1872) & 50 & 57.7 & 0 & 0 & 0 & 0 & 0 & 0 & 0 & 0 & 0 & 0 \\
\hline Cirroforus furcatus (Hartman, 1957) & 25 & 50 & 100 & 115.5 & 0 & 0 & 0 & 0 & 0 & 0 & 0 & 0 \\
\hline Paraonis fulgens (Levinsen, 1883) & 0 & 0 & 0 & 0 & 50 & 100 & 0 & 0 & 0 & 0 & 0 & 0 \\
\hline Hydroides elegans (Haswell, 1883) & 25 & 50 & 0 & 0 & 0 & 0 & 0 & 0 & 0 & 0 & 0 & 0 \\
\hline Malacoceros fuliginosus (Claparède, 1870) & 25 & 50 & 100 & 141.4 & 25 & 50 & 0 & 0 & 0 & 0 & 0 & 0 \\
\hline Spio decoratus Bobretzky, 1871 & 100 & 115.5 & 0 & 0 & 0 & 0 & 600 & 355.9 & 0 & 0 & 25 & 50 \\
\hline Streblospio shrubsolii (Buchanan, 1890) & 0 & 0 & 0 & 0 & 0 & 0 & 17625 & 5194.5 & 150 & 238 & 0 & 0 \\
\hline Exogone verugera Claparède, 1868 & 75 & 150 & 0 & 0 & 0 & 0 & 0 & 0 & 0 & 0 & 0 & 0 \\
\hline
\end{tabular}


Table 6 Results of the two-way ANOVA used to compare the vertical distribution of polychaete number of species, abundance and diversity from the Cymodocea meadow in the Ensenada de los Abades and the Cymodocea and Ruppia meadows at the Bay of Els Alfacs, using meadows and sediment layers as factors. DF: degrees of freedom.

\begin{tabular}{lccccc}
\hline Number of species & Sum of squares & DF & Mean squares & F-Ratio & P \\
\hline Meadows & 9.83 & 2 & 4.91 & 10.76 & 0.0001 \\
Sediment layesr & 26.43 & 2 & 13.22 & 28.94 & 0.00001 \\
Combined effect & 15.93 & 4 & 3.98 & 8.72 & 0.00002 \\
Model error & 23.29 & 51 & 0.46 & & \\
\hline Abundance & \multicolumn{2}{c}{} & & \\
\hline Meadows & 12965.31 & 2 & 6482.65 & 92.96 & 0.00001 \\
Sediment layers & 28717.37 & 2 & 14358.69 & 205.9 & 0.00001 \\
Combined effect & 23767.36 & 4 & 5941.84 & 85.2 & 0.00001 \\
Model error & 3556.58 & 51 & 69.74 & & \\
\hline Diversity & \multicolumn{7}{c}{} & & & \\
\hline Meadows & 2.28 & 2 & 1.14 & 7.37 & 0.002 \\
Sediment layers & 3.97 & 2 & 1.98 & 12.81 & 0.00003 \\
Combined effect & 1.9 & 4 & 0.47 & 3.06 & 0.02 \\
Model error & 7.9 & 51 & 0.15 & & \\
\hline
\end{tabular}



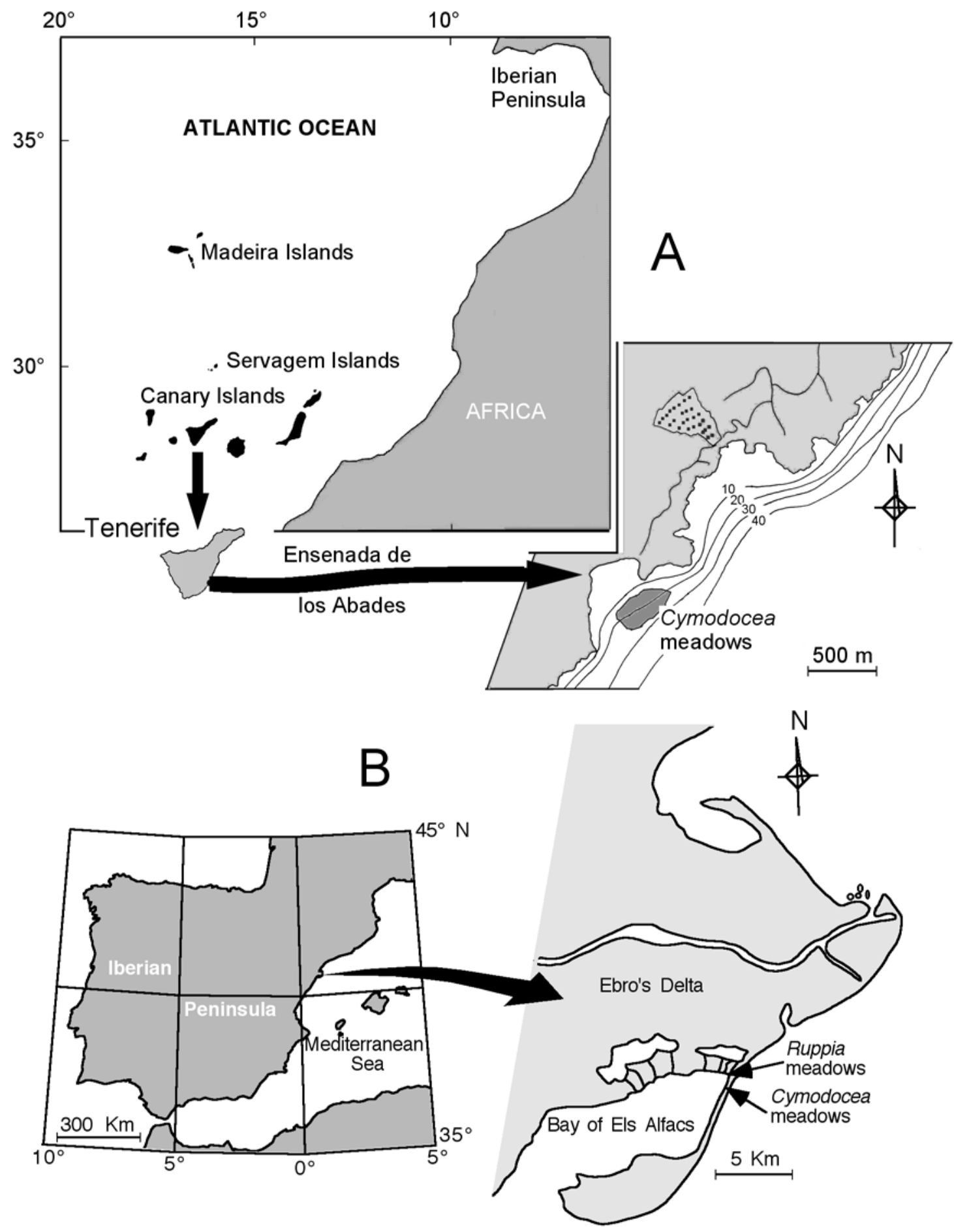

Fig. 1 a.- Location of the Cymodocea nodosa meadows in the Ensenada de los Abades (Eastern coast of Tenerife). b. Location of the Cymodocea nodosa and Ruppia cirrhosa meadows in the Bay of Els Alfacs. 

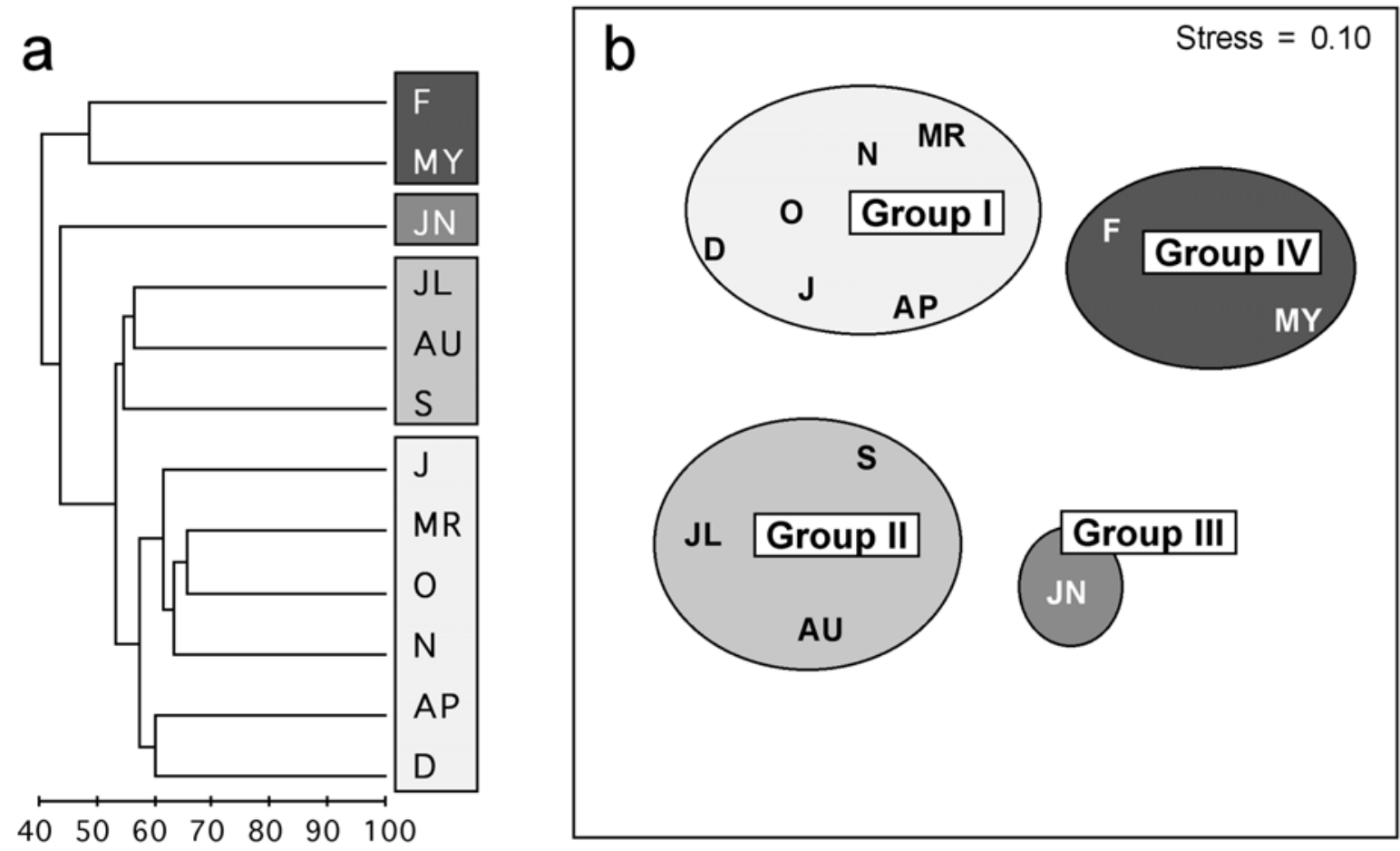

Fig. 2 a.- Cluster of infaunal samples based on annual mean polychaete abundance in the Ensenada de los Abades. b.- Bi-dimensional MDS ordination of the infaunal polychaete samples from the Ensenada de los Abades, based on the abundance similarity matrix. 

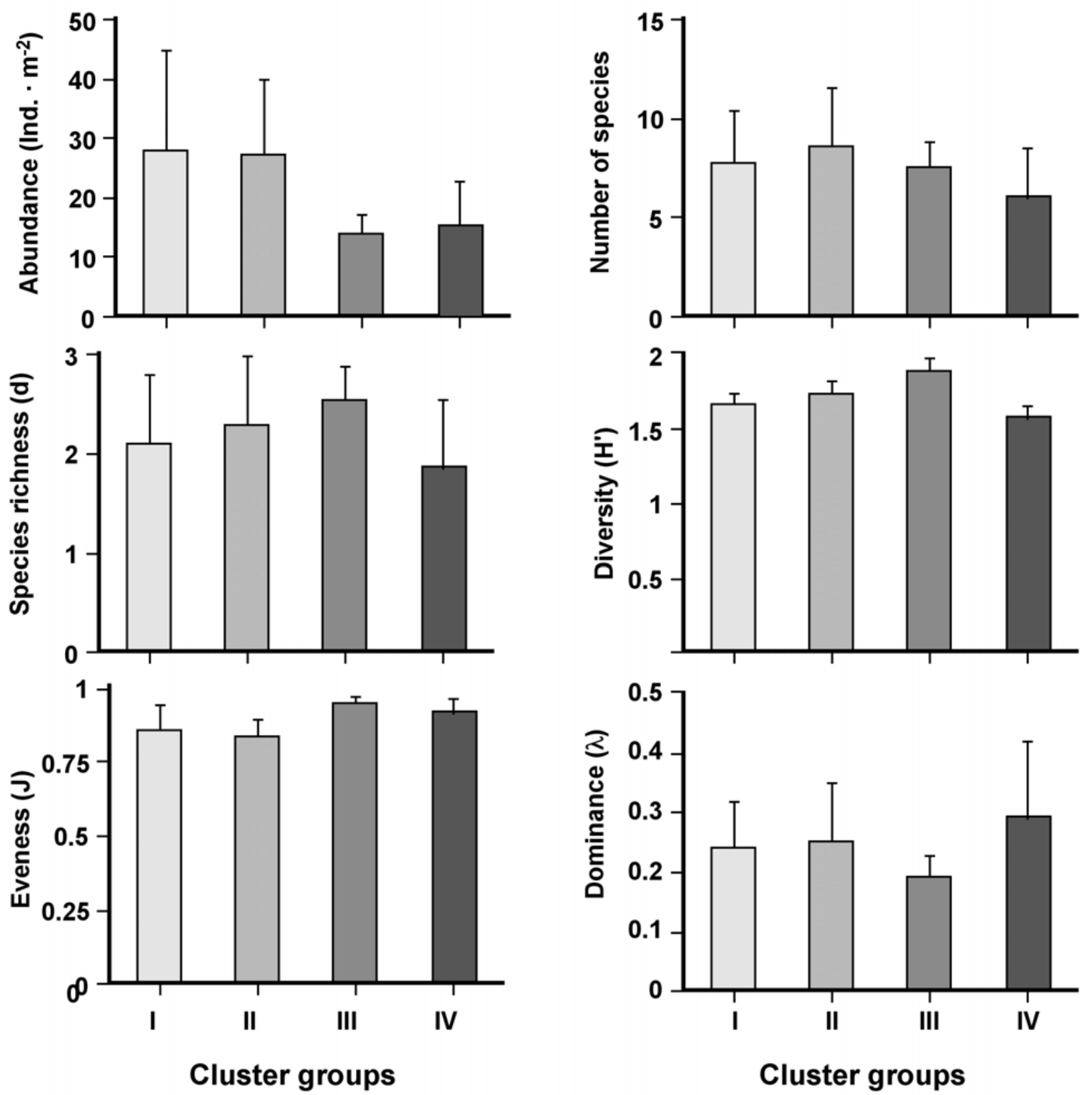

Fig. 3 Mean values of the main biological descriptors (number of species per sample, abundance per square metre, Margalef's species richness, Pielou's evenness, Shannon-Weaver diversity and Simpson's dominance) according to the groups obtained in the multivariate analyses. Bars are standard deviations. 

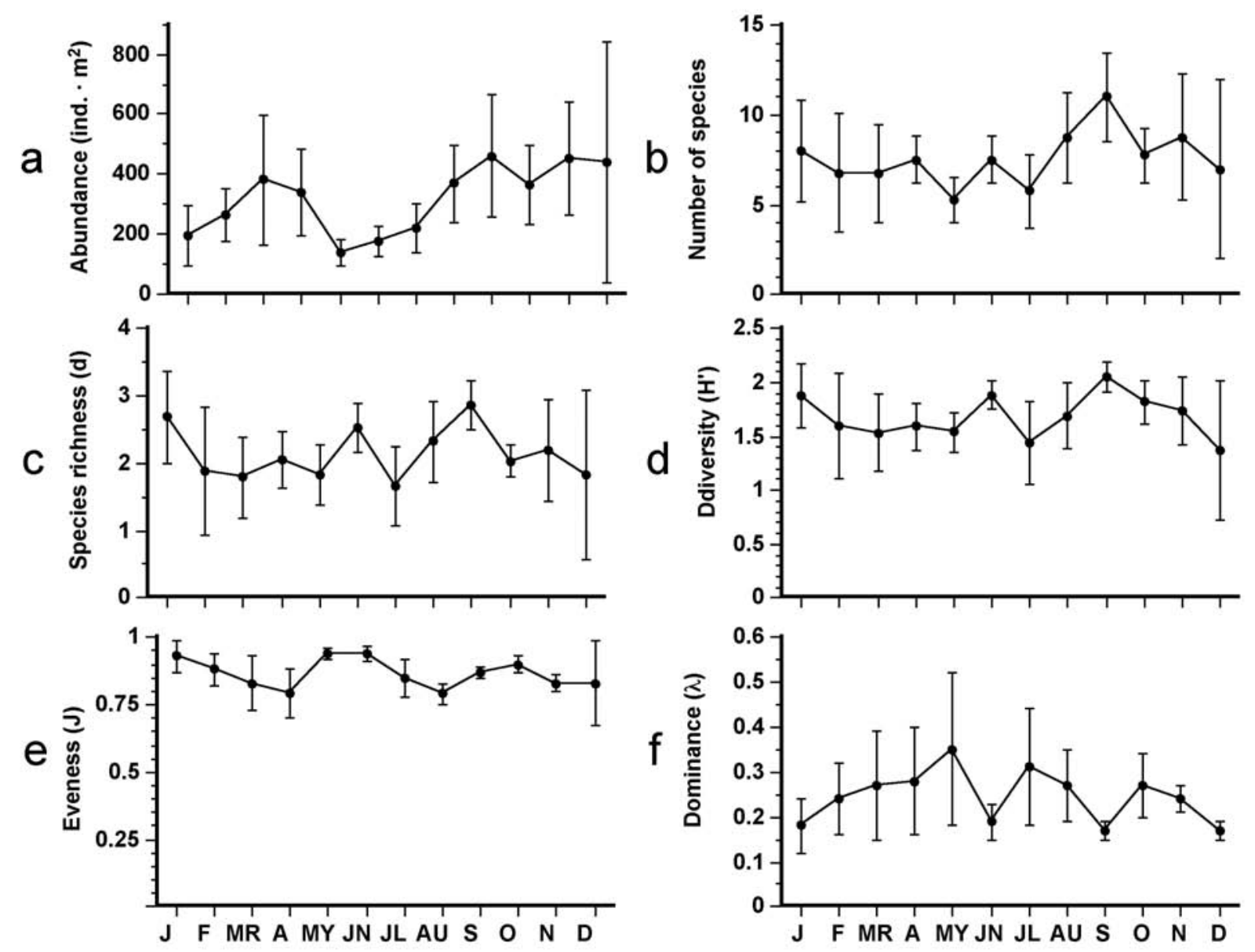

Fig. 4 Annual trends of mean values of the biological descriptors of the polychaete assemblages from the Ensenada de los Abades. a. density as abundance per square metre; b. number of species per sample; c. Margalef's species richness; d. Pielou's evenness; e. Shannon-Weaver diversity; f. Simpson's dominance. Bars are standard deviations. 

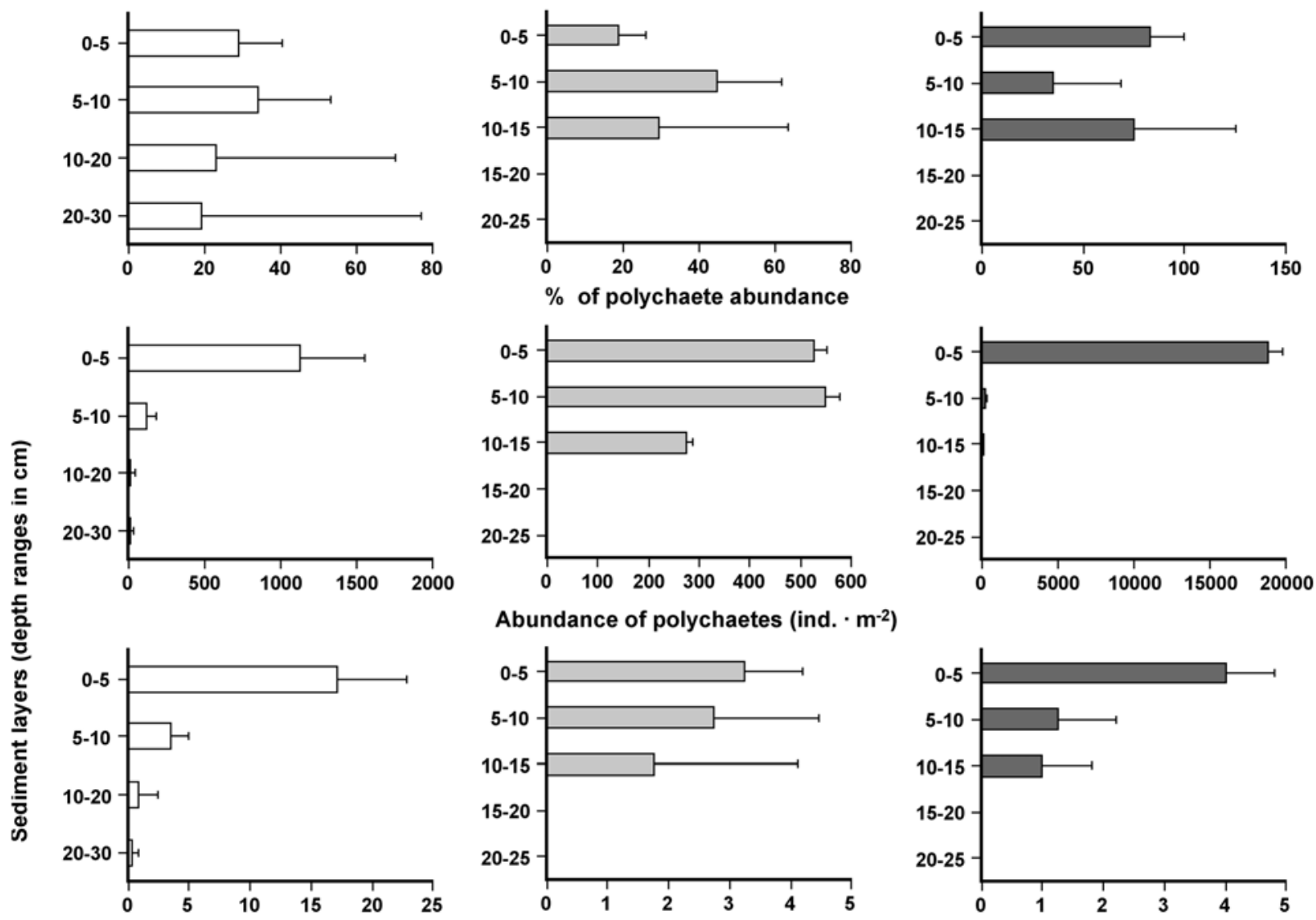

Abundance of polychaetes (ind. $\cdot \mathbf{m}^{-2}$ )
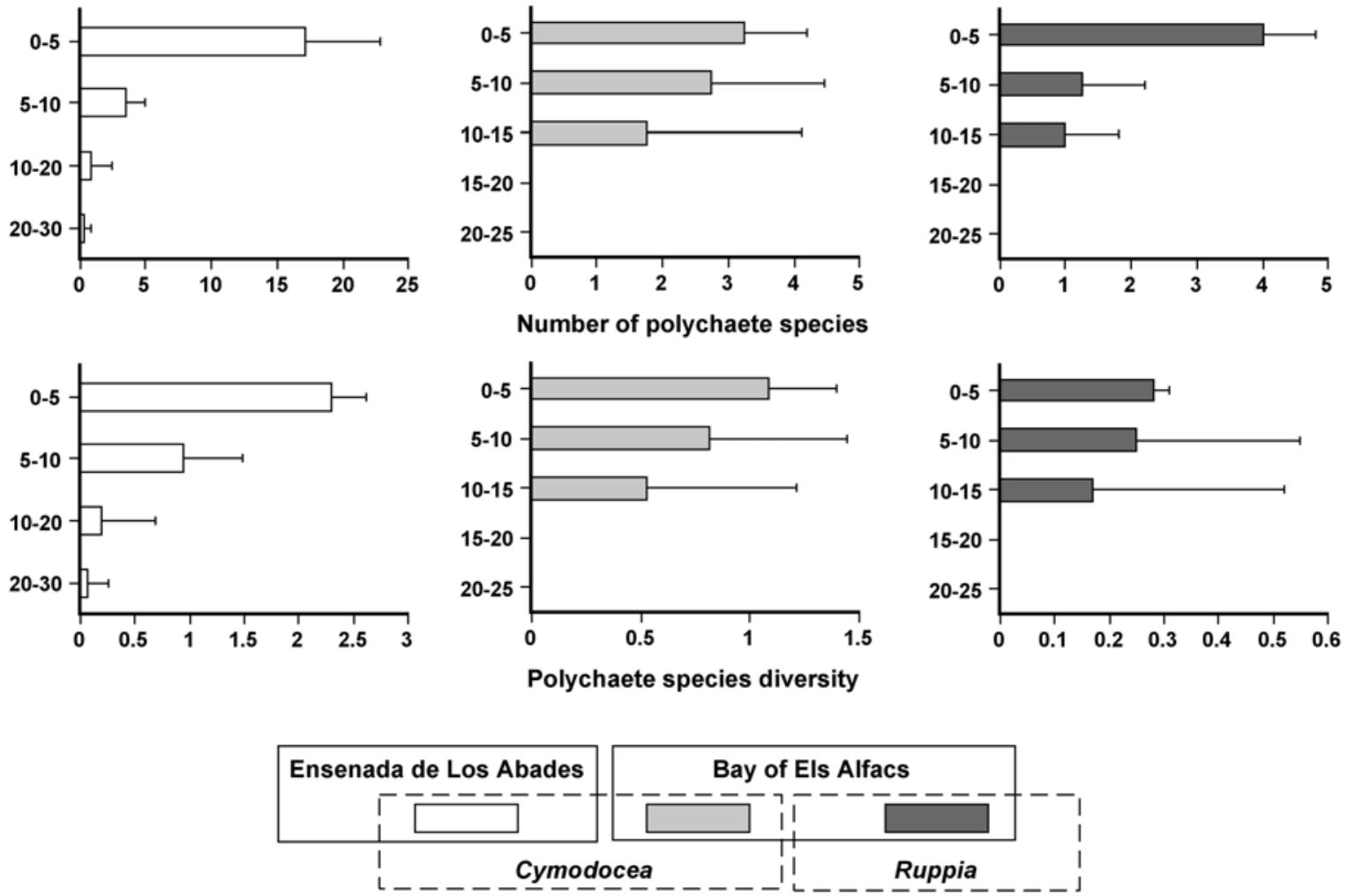

Fig. 5 Vertical distribution of the biological descriptors (percentage with respect to the total macroinfauna, abundance, number of species and Shannon-Weaver diversity) of the polychaete assemblages from Cymodocea (Ensenada de los Abades and Bay of Els Alfacs) and Ruppia (Bay of Els Alfacs) meadows. 